\title{
Obituaries
}

Obituaries should be submitted by email to Laura Pacey at I.pacey@nature.com.

All submitted obituaries should be 350 words maximum in length (apart from obituaries for past presidents of the BDA where the length should be $700-800$ words).

Content of the obituary is down to the individual author, and the approval of the family should be given for the obituary prior to submission to the $B D J$.

\section{PROFESSOR BARRY MICHAEL ELEY}

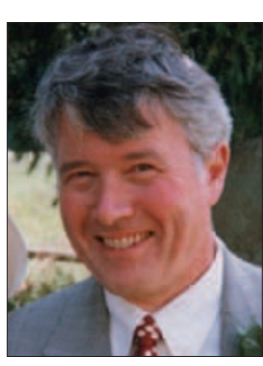

Barry Eley was

born in London on

6 March 1940 and

died on 1 April

2012, following a

brave battle against

Parkinson's disease.

He made major contributions to the

speciality of periodontology, including an internationally recognised textbook and numerous research publications. After graduation from the Royal London Hospital in 1962, he joined the Conservation Department at King's College Hospital Dental School in 1963 as assistant lecturer/registrar and was subsequently appointed senior lecturer and consultant in periodontology in 1980. He remained at King's until his retirement in 2004, having been an active academic board member since 1972 and representing the BDA for the Dental School (1993-1998). He was honorary secretary of the British Society of Periodontology (1984-1987) and later president (1993-1994).

He was awarded a PhD for experimental work on soft tissue reactions to implanted dental amalgam in 1980. That year he also established the first Department of Periodontology at KCHDS. As Head of Periodontology and Director of the Hygiene School, he developed an active and productive department. His research interests ranged from collagen turnover in the periodontal ligament to the pathology of amalgam tattoos and the role of proteolytic enzymes in the pathogenesis and monitoring of periodontal disease and peri-implantitis. The later studies led to further successful PhD projects for postgraduates, though Barry himself continued to engage in laboratory work.

He was awarded a chair in periodontology in 1997. He acted as internal and external examiner for final BDS and examined several $\mathrm{PhDs}$ throughout his career. Following the merger with Guy's and St.Thomas' Hospitals in 1998, Professor Eley was vice-chairman of periodontology and preventive dentistry at King’s College London Dental Institute. His spirited enthusiasm for new ventures and a unique sense of humour will be missed by those who knew him well.

He sadly lost his wife, Julie to breast cancer in 1997. He maintained his passionate support of Crystal Palace football club and other interests in his later years. Particular sympathy is extended to his grandchildren and children Esther and Peter, who gave very moving tributes to their father during his funeral at the church where Barry and Julie had been married.

Stephen Cox, Daphne Agerholm and Mena Soory

\section{PHILIP JOHN ERIC LANG}

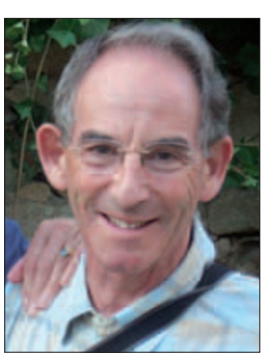

Philip Lang (Phil

to his friends and colleagues) passed away peacefully on March 10 after a long and brave battle with a terminal illness. He was 73. While study-

ing at Guy's Dental School he volunteered to fly to the Middle East with four fellow students in a converted RAF training aircraft. Phil had never flown before, while the inexperienced pilot had not flown beyond Paris. Phil emerged unruffled by their ensuing hair-raising misadventures that included two emergency landings. His determination to see things through was to be a hallmark in his subsequent professional life. He graduated in 1962.

Phil's thirst for knowledge remained unquenched throughout his long and successful years of practice in the Wantage area. He had particular interests in the temporomandibular joint and holistic dentistry and often attended courses in the USA. Integrity and sincerity were his credo both within and outside his profession. His enthusiasm for dentistry was infectious. He was secretary of the Mercia Branch of the BDA, president (and founder member) of the London Dental Fellowship and in 2002 was elected fellow of the Pierre Fauchard Honour Academy. A gentle and good humoured colleague, who never failed to help, he was also much respected within his community where he was chairman of his area Round Table and chairman of the Vale Divisional Youth Committee.

Phil is survived by his wife Rosemary whom he married in 1962 and with whom he shared his love of music. He passed away just four months before their golden wedding anniversary. They have a daughter Penny, a son Robert and four grandchildren to whom we extend our heartfelt condolences.

William Long and Harold Preiskel 